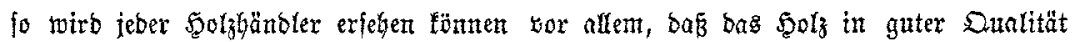

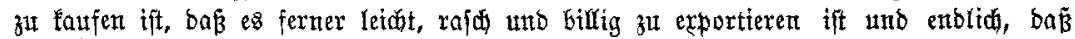

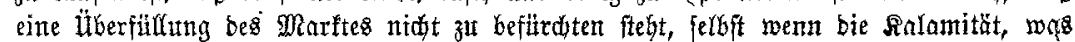
Bott berbüten möge, nod größere Dimenfionen annebmen fullte. - So glanţe auf

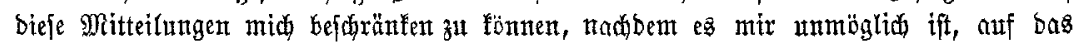

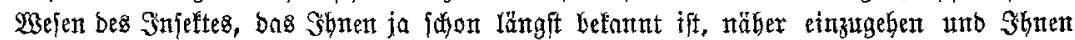

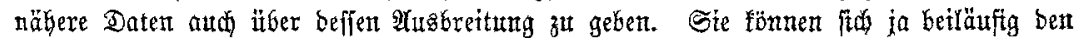

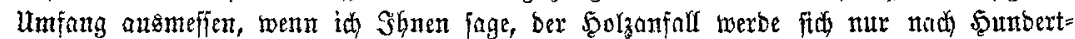

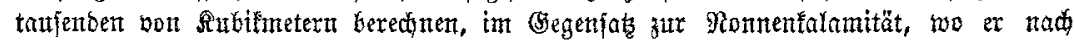



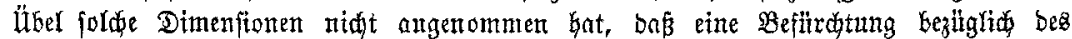

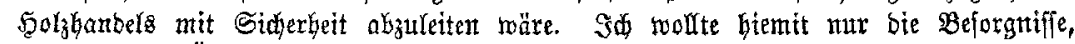

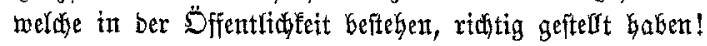

\title{
Thatfäđliche Berthtigung.
}

\section{Bon Dberforffrat Dr. Stoetzer in Eifenact.}

Do Mowemberbeft bes 1895 er Sahrogangs biefer Beitforift bringt in feimen Mit= teilungen einen Beridit über sie Berbandlungen ber 52 . Generntwerjammlung bes

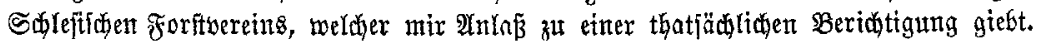

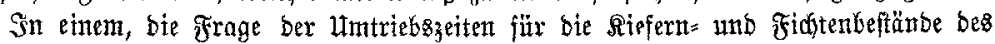

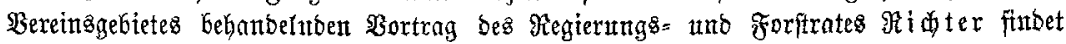

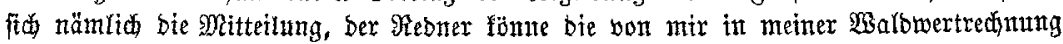

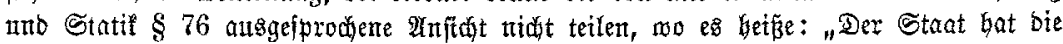

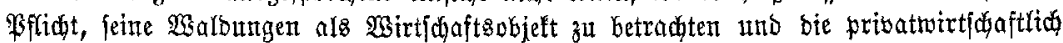

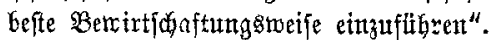

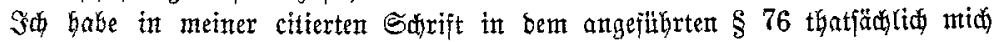

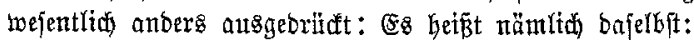

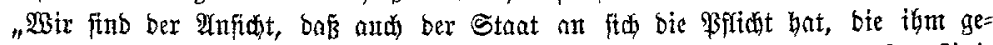

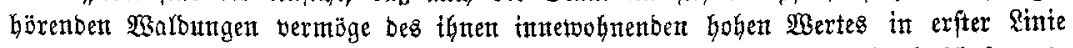

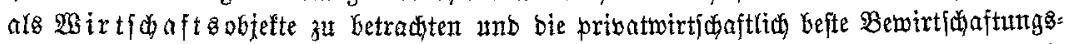

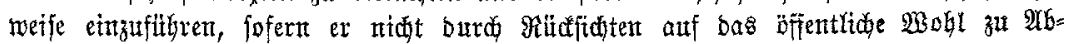

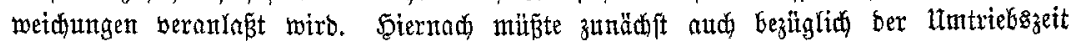

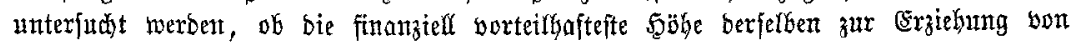

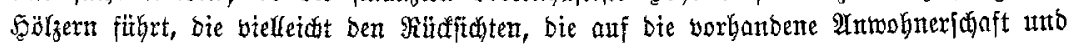

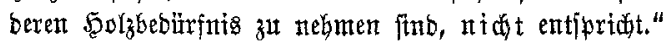

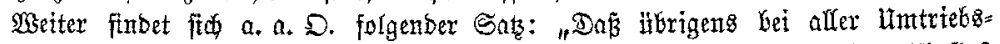

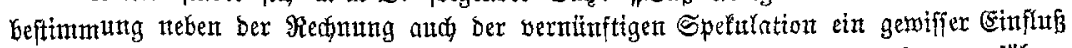

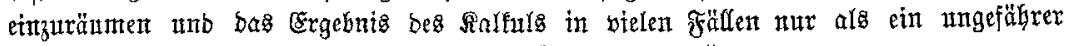

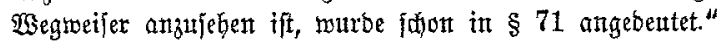

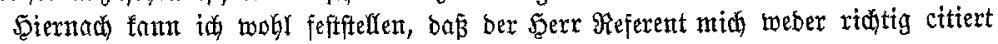

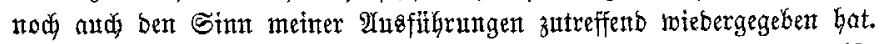

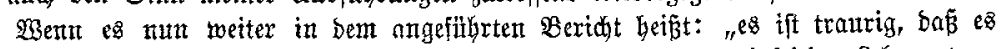

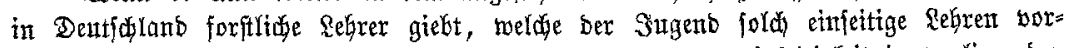

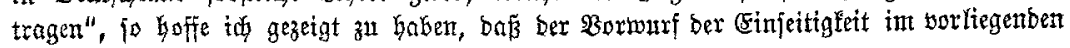
Faffe auf mids nidit paßjt. 